\title{
Liquid/air partition coefficients of six commonly used glycol ethers
}

\author{
G JOHANSON, B DYNÉSIUS
}

From the Division of Work and Environmental Physiology, National Institute of Occupational Health, S-17184 Solna, Sweden

\begin{abstract}
The toxicokinetics of organic solvents depend largely on their tissue solubilities. Liquid/ air partition coefficients (pcs) of six commonly used glycol ethers (2-methoxyethanol (ME), 2ethoxyethanol (EE), 2-isopropoxyethanol (PE), 2-butoxyethanol (BE), 2-ethoxyethyl acetate (EEA), and 1-methoxy-2-propanol (MP)) were determined in vitro using a head space technique. The liquids used were physiological saline, human blood, and olive oil. The pcs were calculated after gas chromatographic quantification of the glycol ethers in the air phase. The water-air pcs ranged from 3800 to 36000 , increasing in the order EEA, BE, MP, PE, EE, ME. These values corresponded closely to the blood/air pcs with one exception-EEA could not be detected in the air phase after addition to blood. The oil/air pcs ranged from 530 to 5400, increasing in the order ME, MP, EE, PE, EEA, BE.
\end{abstract}

Glycol ethers are frequently present as solvents, detergents, or emulsifiers in chemical products used for cleaning, surface coating, and printing. Adverse reproductive effects have been noted in laboratory animals after exposure to 2-methoxyethanol (ME), 2ethoxyethanol (EE), and their acetates, as reviewed by Illing and Tinkler.' Respiratory and percutaneous uptake have been shown for various glycol ethers, indirectly by recording toxic effects and directly by detecting the parent compound in the blood or the acid metabolite in the urine. ${ }^{1-5}$

The absorption, excretion, and distribution rates of organic solvent vapours depend largely on their tissue solubilities, or rather their tissue/air and tissue/tissue partition coefficients. The partition coefficients (pcs or $\lambda)$ are therefore important factors when studying or interpreting the toxicokinetic profile of organic solvents and have been established for many solvents, as illustrated by the compilations made by FiserovaBergerova. ${ }^{67}$ Equations providing the means for estimating the tissue/air pcs whenever the blood/air and oil/air pcs are known have also been described. ${ }^{7}$ Few published data, however, are found on the partitioning of the glycol ethers. An oil/water partition coefficient for EE has been reported ${ }^{8}$ and preliminary data on the partitioning of 2-butoxyethanol (BE) have been used in a pharmacokinetic simulation study. ${ }^{9}$

The aim of the present study was to determine the in vitro water/air, blood/air, and oil/air pcs for ME,

Accepted 14 August 19897
EE, 2-isopropoxyethanol (PE), BE, 2-ethoxyethyl acetate (EEA), and 1-methoxy-2-propanol (MP). The alkoxyethanols were chosen as forming a series of homologues, and because they are in common use. EE and BE, particularly, are often present in chemical products. ${ }^{10}$ The ester EEA is the most often used glycol ether in Sweden whereas MP is often a substitute for the more hazardous 2-alkoxyethanols. ${ }^{10}$

\section{Materials and methods}

\section{CHEMICALS}

Sodium chloride (analytical grade), EE, and PE (for synthesis) were obtained from Merck (Darmstadt, West Germany), ME (HPLC-grade), MP (98\% purity), and EEA ( $99 \%$ purity) from Aldrich (Steinheim, West Germany), BE ( $99 \%$ purity) from Janssen Pharmaceutica (Beerse, Belgium), and carbon disulphide (reagent grade) from J T Baker (Deventer, Holland). Spanish olive oil (Swedish Pharmacopoeia 1946) was purchased from Apoteksbolaget (Stockholm, Sweden). All chemicals were used without further purification.

\section{STANDARD CUR VES}

Standard glycol ether mixtures were prepared as follows. To a test tube containing carbon disulphide were added, $1,2,5,10,20,50,100$, or $200 \mu \mathrm{l}$ of each of the six glycol ethers (ME, EE, PE, BE, EEA, and MP). The amount of carbon disulphide had been previously adjusted so that the final volume would be $5 \mathrm{ml}$. By means of a Hamilton syringe, $2 \mu \mathrm{l}$ of the carbon 
disulphide solution was transferred into a $22 \cdot 4$ (SD $0.2) \mathrm{ml}$ head space vial. The vial was immediately capped with a teflon lined rubber stopper and allowed to equilibrate at $37^{\circ} \mathrm{C}$ for at least 20 minutes before the gas chromatographic analysis. Thus, assuming no losses, the concentration should range from about 0.02 to $4 \mathrm{nl}$ of glycol ether per $\mathrm{ml}$ air $\left(20-4000 \mathrm{mg} / \mathrm{m}^{3}\right)$.

\section{LIQUID/AIR PARTITIONING}

Aliquots of $2 \mathrm{ml}$ of physiological saline ( $0.3 \mathrm{M}$ sodium chloride), olive oil, or pooled fresh human blood were added to a head space vial, identical to the one described above. The blood had been collected and pooled immediately before the experiment and was obtained from the brachial vein of seven healthy volunteers (four men, three women) in a heparinised $10 \mathrm{ml}$ Vacutainer (Beckton Dickinson, Paramus, NJ) tubes. The packed cell volume of the pooled blood was $44 \%$. After allowing the vial to stabilise at $37^{\circ} \mathrm{C}, 2 \mu \mathrm{l}$ of one of the six glycol ethers was added. The vial was rapidly capped and rotated at $37^{\circ} \mathrm{C}$ for at least 20 minutes before the gas chromatographic analysis took place. This procedure was carried out in five replicates for each combination of liquid and glycol ether.

\section{GAS CHROMATOGRAPHIC ANALYSIS}

The glycol ethers in the gas phase of the head space vials were determined by gas chromatography (Perkin-Elmer F45) with flame ionisation detection. A polar, wide bore capillary glass column (Supelcowax 10 (Supelco, Bellefonte, PA), $30 \mathrm{~m} \times 0.75 \mathrm{~mm}$ inner diameter, $1.0 \mu \mathrm{m}$ bonded phase) was used. The temperatures were as follows: head space autosampler $37^{\circ} \mathrm{C}$, needle $200^{\circ} \mathrm{C}$, injector $150^{\circ} \mathrm{C}$, initial column temperature $55^{\circ} \mathrm{C}$, programme rate $2^{\circ} \mathrm{C} / \mathrm{min}$, final column temperature $85^{\circ} \mathrm{C}$, and detector $200^{\circ} \mathrm{C}$. Nitrogen was used as carrier gas at a flow rate of about $20 \mathrm{ml} / \mathrm{min}$. Peak areas were obtained with an integrator (Perkin-Elmer LCI-100). Table 1 gives the retention times of the six glycol ethers.

\section{CALCULATIONS}

By definition, the partition coefficient $(\lambda)$ of a substance is the quotient of its concentration $(C)$ in the two phases at equilibrium:

$$
\lambda_{\text {liq/air }}=\mathrm{C}_{\text {liq }} / \mathrm{C}_{\text {air }}
$$

The concentration in the liquid phase may be expressed as the ratio of the amount of substance $\left(A_{\mathrm{liq}}\right)$ to the volume of the liquid phase $\left(\mathrm{V}_{\text {liq }}\right)$. Assuming no losses, the amount of substance in the liquid phase must equal the amount added minus the amount in the air phase $\left(\mathrm{A}_{0}-\mathrm{A}_{\mathrm{air}}\right)$. Further, the amount in the air phase may be expressed as the concentration of substance in the air phase multiplied by the volume of the air phase $\left(\mathrm{C}_{\text {air }} \times\right.$ $\mathrm{V}_{\text {air }}$ ). Hence, equation 1 may be rewritten as:

$$
\lambda_{\text {liq/air }}=\mathrm{A}_{0} /\left(\mathrm{V}_{\text {liq }} \times \mathrm{C}_{\text {air }}\right)-\mathrm{V}_{\text {air }} / \mathrm{V}_{\text {liq }}
$$

The volumes $V_{\text {liq }}$ and $V_{\text {air }}$ were 2 and $20.4 \mathrm{ml}$, respectively, whereas the amount of added glycol ether was usually $2000 \mathrm{nl}$. In those cases equation 2 could be reduced to:

$$
\lambda_{\text {liq/air }}=2000 /\left(2 \times C_{\text {air }}\right)-20 \cdot 4 / 2=1000 / C_{\text {air }}-10 \cdot 2(3)
$$

Since $\lambda$ is dimensionless, the units used are of no importance. For convenience, the unit $\mathrm{nl}$ was used for the amount of liquid glycol ether and $\mathrm{ml}$ for the volume of the phases. The concentrations of the glycol ethers in the air phase were calculated by solving the regression equations of the standard curves.

\section{Results and discussion}

No gas chromatographic peaks that might interfere with the analyses were seen when physiological saline, olive oil, or blood were equilibrated without any added glycol ether. Furthermore, by analysing the vapour of the individual glycol ether it was found that none caused impurity peaks that would interfere with any of the other five in the standard mixture. After liquid/air partitioning of some of the glycol ethers, however, impurity peaks were observed in the air phase. To avoid possible interference with the determination of the other compounds, the liquid/air partitioning experiments were conducted with single glycol ethers.

Repeated experiments showed that the gas chromatographic response was stable from 20 minutes up to at least seven hours after the preparation of the

\begin{tabular}{|c|c|c|c|c|}
\hline Compound & $\begin{array}{l}\text { Retention } \\
\text { time (min) }\end{array}$ & $\begin{array}{l}\text { No of } \\
\text { samples }\end{array}$ & Regression equation & $\begin{array}{l}\text { Coefficient of } \\
\text { correlation }\end{array}$ \\
\hline $\begin{array}{l}\text { 1-methoxy-2-propanol (MP) } \\
\text { 2-methoxyethanol (ME) } \\
\text { 2-ethoxyethanol (EE) } \\
\text { 2-isopropoxyethanol (PE) } \\
\text { 2-ethoxyethyl acetate (EEA) } \\
\text { 2-butoxyethanol (BE) }\end{array}$ & $\begin{array}{r}3 \cdot 9 \\
4 \cdot 9 \\
5 \cdot 9 \\
6 \cdot 2 \\
8 \cdot 4 \\
12 \cdot 4\end{array}$ & $\begin{array}{l}33 \\
35 \\
33 \\
32 \\
35 \\
29\end{array}$ & $\begin{array}{l}\ln (\text { peak area })=15.841+1.025 \times \ln (\text { conc }) \\
\ln (\text { peak area })=15.677+1.081 \times \ln (\text { conc }) \\
\ln (\text { peak area })=15.849+1.081 \times \ln (\text { conc }) \\
\ln (\text { peak area })=16.090+1.035 \times \ln (\text { conc }) \\
\ln (\text { peak area })=15.907+1.080 \times \ln (\text { conc }) \\
\ln (\text { peak area })=16.037+1.230 \times \ln (\text { conc })\end{array}$ & $\begin{array}{l}0.997 \\
0.998 \\
0.999 \\
0.999 \\
0.997 \\
0.994\end{array}$ \\
\hline
\end{tabular}

Table 1 Retention times and regression equations of the standard curves of six glycol ethers, as determined by head space gas chromatography 
standard and sample vials. It made no difference to the results whether the glycol ethers were added in the liquid phase or to the wall of the upper part of the vial. The standard curves of the six glycol ethers were linear over the whole concentration range studied $(0 \cdot 02-4 \mathrm{nl} /$ $\mathrm{ml})$; their regression equations are given in table 1 . The observations suggest that distribution equilibrium between the phases is reached within 20 minutes, and that any systematic errors-for example, due to leakage before or after capping the head space vial or adsorption or condensation on the glass wall of the vial-are negligible. The highest concentrations achieved in the partitioning experiments were never more than about $5 \%$ of the saturation concentration at $25^{\circ} \mathrm{C}$ for any of the glycol ethers.

Table 2 shows the experimentally determined liquid/air pcs with the calculated liquid/liquid pcs. The water/air pcs range from about 3800 to 36000 , with increasing values in the order EEA, BE, MP, PE, EE, $M E$. The blood/air pcs range from about 8000 to 33000 , increasing in the order BE, MP, PE, EE, ME. After the addition of EEA to blood, no acetate ester but only EE could be detected in the air phase. This was most probably due to rapid hydrolysis by blood esterases. Several glycol ether acetates have been shown to undergo hydrolysis in the presence of carboxyl esterases recovered from various mouse tissues, including blood. ${ }^{11}$

The oil/air pcs increase from about 530 to 5400 in the order ME, MP, EE, PE, EEA, BE. For BE and EEA the oil/water pcs approximate unity whereas the preference for water is pronounced among the others. Similar to the results in table 2, a pc of 0.07 (range $0.052-0.085, \mathrm{n}=5$ ) was reported for $\mathrm{EE}$ after equilibration between olive oil and distilled water at $25^{\circ} \mathrm{C},{ }^{8}$ whereas a coefficient of 0.7 (range $0.56-0.91$, n $=6$ ) was obtained after partitioning of BE between olive oil and Krebs-Henseleit buffer at $37^{\circ} \mathrm{C} . .^{12}$

The solubility in blood is closely related to that in water $\left(\lambda_{\text {water/bood }} \approx 1\right.$, range $\left.0 \cdot 86-1.09\right)$ for the five glycol ethers studied. This contrasts with the highly fat soluble solvents such as chlorinated hydrocarbons, where small amounts of blood fat cause a significantly higher solubility in blood than in water. ${ }^{13}$ Lipophilic and hydrophilic solvents also differ in their preference for other biological tissues. Lipophilic solvents have tissue/blood pes greater than unity, and the coefficient increases with increased fat content in the tissue. By contrast, hydrophilic solvents will distribute rather uniformly with a weak preference for blood. In other words, the tissue/air pcs will be determined by the $\lambda_{\text {blood/air }}$ value for a hydrophilic solvent, whereas they will depend on both the $\lambda_{\text {blood/air }}$ and the $\lambda_{\text {oil/air }}$ values for a lipophilic solvent. ${ }^{7}$

As seen in table 2, the solubility in water (and blood) decreases with increasing number of carbon atoms in the alkoxyethanol (ME, EE, PE, BE) and in the methoxy alkanol (ME, MP) series of homologues. Conversely, the solubility in oil increases. Also the acetate ester (EEA) is less soluble in water and more soluble in oil than is the parent alcohol (EE). Thus the relation between the pcs of the studied glycol ethers are consistent with what might be expected from their chemical structure. The blood/air pes of lower aliphatic alcohols are reported to range between about 450 (isobutanol) and 2900 (methanol). ${ }^{714}$ The presence of an ether bond in the glycol ethers increases the polarity and may contribute to both the lower vapour pressure and the higher blood/air pcs, as compared with the aliphatic alcohols.

Owing to the high solubility in water and blood, a high respiratory uptake of all six glycol ethers is expected. This has been experimentally shown for EEA in dogs, ${ }^{16} \mathrm{MP}$ in rats, ${ }^{17}$ and for EE and BE in man. ${ }^{35}$ Further, one would expect the rate of the respiratory uptake to be limited only by pulmonary ventilation and not by the pulmonary blood flow (cardiac output) or the concentration of glycol ether in the body fluids. ${ }^{18}$

The high partition coefficients of the glycol ethers make it difficult to use head space techniques for detection in biological specimens. If people are exposed to BE at $100 \mathrm{mg} / \mathrm{m}^{3}$ (the Swedish hygienic limit) the solvent concentrations may not exceed $7 \mu \mathrm{M}$ in blood and $1 \mu \mathrm{M}$ in urine. ${ }^{5}$ The corresponding concentrations in the air phase after equilibration at $37^{\circ} \mathrm{C}$ would be about 100 and 1000 times less than the lowest concentration in the BE standard used in the present study. No indication of concentration dependence in the blood/air partitioning was seen at concen-

Table 2 Partition coefficients of six glycol ethers as determined by head space gas chromatography (mean (SE), $n=5)$

\begin{tabular}{|c|c|c|c|c|c|c|}
\hline Compound & Water/air*† & Blood/air* $\ddagger$ & Water/blood\$ & Oil/air ${ }^{*} \|$ & Oil/water & Oil/blood** \\
\hline $\begin{array}{l}\text { 1-methoxy-2-propanol (MP) } \\
\text { 2-methoxyethanol (ME) } \\
\text { 2-ethoxyethanol (EE) } \\
\text { 2-isopropoxyethanol (PE) } \\
\text { 2-ethoxyethyl acetate (EEA) } \\
\text { 2-butoxyethanol (BE) }\end{array}$ & $\begin{array}{r}12280(234) \\
35869(437) \\
23069(239) \\
12349(141) \\
3822(71) \\
7051(185)\end{array}$ & $\begin{array}{lr}12383 & (299) \\
32836 & (1350) \\
22093 & (538) \\
14416 & (565) \\
-7965 & (61)\end{array}$ & $\begin{array}{l}0.992 \\
1.092 \\
1.044 \\
0.857 \\
-\quad \\
0.885\end{array}$ & $\begin{array}{r}696(11) \\
529(11) \\
962(6) \\
1616(26) \\
4860(60) \\
5446(70)\end{array}$ & $\begin{array}{l}0.057 \\
0.015 \\
0.042 \\
0 \cdot 131 \\
1.271 \\
0.772\end{array}$ & $\begin{array}{l}0.056 \\
0.016 \\
0.044 \\
0 \cdot 112 \\
-\quad \\
0.684\end{array}$ \\
\hline
\end{tabular}

*Obtained by head space gas chromatography at $37^{\circ} \mathrm{C}$. $†$ Physiological saline— that is, $0 \cdot 3 \mathrm{M}$ sodium chloride. $\ddagger$ Pooled human blood. $\$ \mathrm{Calculated}$ as: $\lambda_{\text {water/lood }}=\lambda_{\text {water/air }} / \lambda_{\text {tlood/air }} \|$ Olive oil. $\left\lceil\right.$ Calculated as: $\lambda_{\text {oil/water }}=\lambda_{\text {oil/air }} / \lambda_{\text {water/air }}{ }^{* *}$ Calculated as: $\lambda_{\text {oil/bood }}=\lambda_{\text {oil/air }} / \lambda_{\text {blood/air }}$ 
trations down to about $1 \mathrm{mM}$ of glycol ether in blood. Nevertheless, it cannot be excluded that saturation binding may be important at biologically relevant concentrations, which would further aggravate the analytical difficulties when using head space techniques.

Despite the high water/air pcs of the studied glycol ethers, considerable air concentrations may be attained-for example, when a product containing one of these substances is drying after application on large areas, such as during indoor painting or cleaning. Air concentrations of $B E$ up to $45-60 \mathrm{mg} / \mathrm{m}^{3}$ were measured after painting the ceiling with a water based product containing $0.4 \% \mathrm{BE}^{19}$

In conclusion, the six studied glycol ethers have high blood/air and water/air pcs. Therefore a high respiratory uptake is to be expected. Difficulties may arise when head space techniques are used in the analysis of glycol ethers in biological specimens. The measured pcs are consistent with the chemical structure of the studied glycol ethers. The oil/blood pcs are sufficiently low to assume that these solvents distribute uniformly between tissues. Despite the high water/air pcs, considerable air concentrations of glycol ethers may be reached-for example, during painting or cleaning.

We wish to express our gratitude to Dr Marianne Byfält Nordqvist for valuable discussions and comments on the manuscript.

Requests for reprints to: Gunnar Johanson.

\section{References}

1 Illing HPA, Tinkler JJB. Toxicity review 10: glycol ethers. London: Health and Safety Executive, 1985.

2 Bartnik FG, Reddy AK, Klecak G, Zimmermann W, Hostynek JJ, Kunstler K. Percutaneous absorbtion, metabolism, and hemolytic activity of n-butoxyethanol. Fundam Appl Toxicol 1987;8:59-70.

3 Groeseneken D, Veulemans H, Masschelein R. Urinary excretion of ethoxyacetic acid after experimental human exposure to ethylene glycol monoethyl ether. Br J Ind Med 1986;43:61 5-9.

4 Johanson G, Fernström P. Percutaneous uptake rate of 2-butoxyethanol in the guinea pig. Scand $J$ Work Environ Health 1986:12:499-503.

5 Johanson G, Kronborg H, Näslund PH, Byfält Nordqvist M. Toxicokinetics of inhaled 2-butoxyethanol (ethylene glycol monobutyl ether) in man. Scand $J$ Work Environ Health 1986;12:594-602.

6 Fiserova-Bergerova V. Gases and their solubility: A review of fundamentals. In: Fiserova-Bergerova V, ed. Modeling of inhalation exposure to vapors: uptake, distribution, and elimination. Vol 1. Boca Raton, Florida: CRC Press, 1983:3-28.

7 Fiserova-Bergerova V, Diaz M. Determination and prediction of tissue-gas partition coefficients. Int Arch Occup Environ Health 1986;58:75-87.

8 Macy R. Partition coefficients of fifty compounds between olive oil and water at $20^{\circ} \mathrm{C}$. Journal of Industrial Hygiene 1948;30:140-3.

9 Johanson G. Physiologically based pharmacokinetic modeling of inhaled 2-butoxyethanol in man. Toxicol Lett 1986;34:23-31.

10 Johanson G, Rick U. Occurrence of glycol ethers in chemical products in Sweden. Stockholm: Arbetarskyddsverket, 1986. (Arbete och hälsa 1986:13.) (English abstract.)

11 Stott WT, McKenna MJ. Hydrolysis of several glycol ether acetates and acrylate esters by nasal mucosal carboxylesterase in vitro. Fundam Appl Toxicol 1984;5:399-404.

12 Johanson G. Toxicokinetic studies of 2-butoxyethanol. Stockholm: Arbetarskyddsstyrelsen, 1984. (Undersökningsrapport 1984: 39.) (English abstract.)

13 Sato A, Nakajima T. A structure-activity relationship of some chlorinated hydrocarbons. Arch Environ Health 1979;34:69-75.

14 Lindqvist T. The partition coefficients blood/air and water/air for some common solvents. Stockholm: Arbetarskyddsverket, 1977. (Arbete och hälsa 1977:8.) (English abstract.)

15 Pezzagno G, Ghittori S, Imbriani M, Capodaglio E. The measure of solubility coefficient of gases and vapors in blood. II. The largely used industrial solvents. G Ital Med Lav 1983;5:49-63. (English abstract.)

16 Guest D, Hamilton ML, Deisinger PJ, Di Vincenzo GD. Pulmonary and percutaneous absorption of 2-propoxyethyl acetate and 2-ethoxyethyl acetate in Beagle dogs. Environ Health Perspect 1984;57:177-83.

17 Stott WT, McKenna MJ. The comparative absorption and excretion of chemicals by the upper, lower and intact respiratory tract of rats. Fundam Appl Toxicol 1984;4:594-602.

18 Fiserova-Bergerova V. Physiological models for pulmonary administration and elimination of inert vapors and gases. In: Fiserova-Bergerova V, ed. Modeling of inhalation exposure to vapors: uptake, distribution, and elimination. Vol 1. Boca Raton, Florida: CRC Press, 1983:73-100.

19 Kragh Hansen M. Water-based paints-effects on the work environment. Copenhagen: Arbejdsmiljøfondet, 1986:1. (English abstract.) 